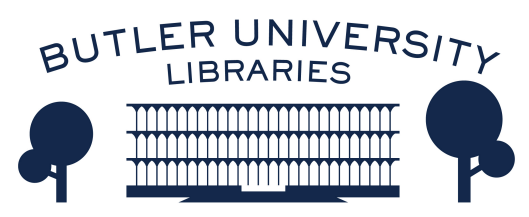

Journal of Hindu-Christian Studies

Volume 3

Article 12

January 1990

\title{
Viewpoints: In Dialogue with Hindus? My Experience and Reflections
}

\author{
Sr. Vandana
}

Follow this and additional works at: https://digitalcommons.butler.edu/jhcs

Part of the Religion Commons

\section{Recommended Citation}

Vandana, Sr. (1990) "Viewpoints: In Dialogue with Hindus? My Experience and Reflections," Journal of Hindu-Christian Studies: Vol. 3, Article 12.

Available at: https://doi.org/10.7825/2164-6279.1035

The Journal of Hindu-Christian Studies is a publication of the Society for Hindu-Christian Studies. The digital version is made available by Digital Commons @ Butler University. For questions about the Journal or the Society, please contact cbauman@butler.edu. For more information about Digital Commons @ Butler University, please contact digitalscholarship@butler.edu. 
34 Viewpoints

I would call this kind of procedure a descending dialogue, whereas starting from the social or any other level would be an ascending way of dialogue, with the inherent danger of taking any of these levels as ultimate.

\section{In Dialogue with Hindus? My Experience and Reflections}

Sr. Vandana, Jeevan Dhara Ashram

Garhwal, Himalayas

\section{Wondrous Vistas}

Today, in our pluralistic global village, with its technological civilization, ecological disasters, socio-economic-political oppression apparently crumbling churches, and religion seemingly becoming increasingly redundant especially in the West, wondrous vistas are opened up in the spiritual world. For, I do believe, that as religions in past centuries often served to divide us, in the coming decades and century, spirituality will unite us more and more. "Indeed the hour is coming and is already here... when the Father will be worshipped in spirit and in truth" (John 4.2324), irrespective of religions. Today too, it is hardly possible to be a good Christian or indeed, a good follower of any faith without being conscious of and practically involved in some form of Interfaith Dialogue.

If, about twenty years ago, M. M. Thomas had said that in the transformation of every religion, the meeting with another religion plays an important part, ${ }^{1}$ today we can add that it plays an essential part in our own spiritual transformation. This is more visible and tangible in the West, where so many have been and are so greatly influenced by Eastern religions and meditation practices, that the Vatican's Congregation for the Doctrine of the Faith has even thought it fit to release a cautionary, official guidance on the subject in late 1989. Dr. Panikkar has aptly said that our neighbour's faith is part of our own religious development. To love our neighbours, he says, one must know their faith. And he adds significantly: "If we are not able to, in some way, attain the religious experience of our co-citizens, we cannot pretend to have understood their beliefs, much less presume to pass judgement on them". 2 This has also been my growing conviction.

This article will be written primarily from my experiential knowledge, for Dialogue is primarily Praxis - issuing in theologizing. ${ }^{3}$ A three-fold "Guru Kripa". (Grace of the Master)

I consider this pure gift; by the grace of God; I feel so enormously enriched through my contacts with many kinds of Hindus. Here I will deal with some who were simple, saintly and scholarly. I trust that I will be forgiven if I speak mostly in the first person singular, and sometimes in the plural.

a) The "we" I may slip into will refer to my English colleague and Sr. Eeshpriya Mataji with whom I have been closely involved in this venture for the past twenty years. Her creative and extraordinarily sensitive way of listening to and learning from another culture and faith have been a pure gift of God for me. Without her, I think I 
might have merely skirted the shores of "Ganga Mata" instead of plunging into her waters, and remained in the foothills of "Father Himalayas" without trying to climb higher.

b) Another Godgiven gift that facilitated our Dialogue with Hindu friends is the fact of myself having been born in a "non-Christian" family. (Incidentally, this word should be definitely banished from our vocabulary. Who amongst us would like to be called a "Non-" anything?) I did not grow up with the usual hangups, fears, a superiority complex which some Christians suffer from, nor the general ignorance about Indian, in this case, Hindu customs and traditions.

c) But above all, the third and ineffable gift without which I would not be where I am, is the privilege of having learnt (experientially) the significance in the spiritual life of the Guru-shishya (master-disciple) relationship in the Hindu tradition.

Privileged to meet and sit at the feet of a wise man rooted in God, for six months each year in his ashram (for five years) we saw Interfaith Dialogue lived out daily. His ideal was that a Muslim should become a better Muslim, a Christian a better Christian, as a result of meeting us. We saw him, rooted in Orthodox Hinduism, yet showing reverence to the Scriptures and teachings of other faiths, with the same humility with which he touches the feet of all. Attributing all the good he does to his Gurudev Swami Sivananda, he urges all to say besides his "Universal Prayer," the Our Father and the Prayer of St. Francis. He has, in fact, been called "St. Francis of Rishikesh" and, like him, is "an instrument of peace," whether in India or abroad. Indeed, does not being involved in Dialogue mean we become peacemakers, bridgebuilders and people who create communion? Something urgently needed and important above all in our country-torn apart with communalism?

Familiar with the spirit and teachings of Christ and Christian saints and mystics, he is peculiarly at home with Christians and has helped innumerable lay and religious people to become more spiritual. He was closely united in spirit with Swami Abhishiktananda (the Benedictine, Henri le Saux). He once told us how they the Hindu and Christian monks sat together and just laughed. Words have little meaning at this stage of Dialogue. Often, as I was to learn later, when we are united in the One Spirit, Ekamevamadvaitiyam, we can experience a deeper joy of union and feel closer to our Dialogue partners than with people who may share the same religion as we, but are not on the same spiritual wave-length.

The best way to learn how to Dialogue (as indeed how to live!) was, we realized, to dwell with a living 'murti' of Dialogue. This threw light on why the first question of the disciples of Jesus was: "Master, where do you live?"

\section{The Challenge of Dialogue with Hindus}

From the outset we delighted in dialoguing with people-Hindus. We never thought of dialoguing with "Hinduism," a word which in any case is never found in the Scriptures, and only came into existence out of confrontation with Islam and Christianity. ${ }^{4}$ I do not want to imply that all the way our path was strewn with roses. The thorns often made themselves felt, but all the way we felt was the Way, that we 


\section{Viewpoints}

were in/on the Way - even though many Christian friends thought we might be on the way to perdition. 5

a) Inter-religious dialogue is not easy for several reasons: not only because of the many years of suspicion and estrangement, but also because "we do not have any paradigms from past history for this new venture." 6

It was in fact precisely this - having to "make" our own history - which made/ makes our life all the more interesting and provides a challenge both to us and to our faith. It really means finding or creating out of our inner life, as much as from external situations, as Jesus did. "I speak the things which I have seen with my Father" (John 8.38) - an experiential knowledge of the heart. A symbol such as would be intelligible and acceptable to our Hindu friends, arising out of their context, categories and experience. More recently, the challenge has become even more exciting, since we have had the privilege of being invited to give sadhana saptah's, retreats, satsangs or days of sadhana to mixed groups of Hindus and Christians, in Calcutta, Delhi, etc. At our Ashram Satsangs too there is generally a mixed group of Garhwalis from our village who are Hindi-speaking Hindus, and English-speaking Christians from India and abroad. Did not John write his Gospel to make it intelligible to the "Hellenised" Christians? And did not Paul have two years of "dialegomenos" in Ephesus, with the Greeks in terms of their own traditions and background? And did not Philo of Alexandria (first century) explain the Books of Moses with the help of Greek Philosophy? Sometimes Hindus came to thank us for elucidating their own beliefs to them, while Christians are often delighted to see revealed "the hidden and unknown Christ of Hinduism." And so our joy is redoubled!

b) $A$ pure heart. Interfaith Dialogue is not easy also because it needs great purity of heart, which can "see God" in our Hindu Dialogue partners and their faiths (Matthew 5.8). Or as the Isa Upanishad and the Bhagavad Gitā had said earlier: "to see the Self in all beings and all beings in the Self." 7 This text threw light for me in a "lucid" way on what it truly involved in practice "to love my neighbour as my Self," surely not as we love our ego-self! We need the "third eye" to perceive the One who alone is - in all of us, the true Self, the Source of all our life, love, all faiths.

In other words, Dialogue to be mutually fruitful implies that to find the Spirit/Self/Atman, the first prerequisite is to be willing to die to the ego-self; what all the Asian religions teach us about renunciation of the ahamkar, Jesus was later to put it beautifully: "Unless the grain of wheat falling into the ground die, itself remains alone. But if it dies, it brings forth much fruit" (John 12.20). Only so, one may be sure that it is the Spirit in us - the real Doer - who does the "dialoguing." "I do nothing of my own initiative, but I speak these things as the Father taught me" (John 8.28). This word came alive when our revered Guru taught us something. When we asked his blessing on our first "going forth" to answer an invitation to give retreats (always based on 'Indian Spirituality' - which, if we are to call a spade a spade, means, for us, "Hindu-Christian Spirituality), he said yes, but advised that we should never offer to give retreats on our own initiative, but only respond when 
"called" upon. This good sound counsel has helped us to beware of the ego-the ubiquitous, ever-ready "do-gooder" before one is ready to do good, to teach before one has learnt! I often wonder if the zeal of Christians is not sometimes a real block to Dialogue. Often ignorant of the spiritual riches of the Hindus, the Christians long to bring them to the Light! There are two more things that can render Dialogue very difficult, but fortunately, in our case they have proved to be advantageous.

c) Our life style. The life style of most Christians, in general, can be, and often is, another block. It makes us seem foreign, as though Christians did not own and were not proud of Indian culture. But living as we do an Ashram life style 8 is actually an aid to Interfaith Dialogue, as I have often shown in writings, and in life. It is a positive aid to Interfaith Dialogue because an Ashram forms a natural "locus," as it were, for dialogue, theologizing, and all kinds of creative activities, with people of different faiths. When studying "The Word" last year, it seemed quite nature to invite Hindu, Sikh, Jain and Muslim friends to expound a text on "The Word," each from his own Scriptures.

Being an open community, not only in the sense of open to men and women of all religions and races, castes and creeds, but also in the sense of "open-minded", it feels normal and natural to have such "satsangas" (assemblies of Truth-seekers who meet and share). In such lifestyle, everything is open and symbolic; hence everything speaks, gives a message: the way we think, pray, talk, dress, eat (it surprises some that we can be totally vegetarian, having only satvic food-simple, pure and not too pungent), etc. the art on our walls, the music we sing and play, the liturgies and Indian festivals we celebrate. This not only facilitates their feeling at home when they visit the ashram but also contacts with them in the bazaar, going to their homes, attending their weddings and funerals. This close contact does not only make us feel "one" with them in their joys and sorrows, but also enables us to enter into their prayers and customs, ways of seeing and doing. Not only does it open up a new "world view" for us, but it also surprises them with joy to see Christians at home with and so ready to participate in their life, feasts, fairs and prayers. It dispels a prejudice here, a fear there, and clears the way for closer bonds. It enables both sides to see that the common bonds that bind us together are stronger than the differences that seem or threaten to divide us.

d) The role of women in dialogue. Being women could also have been a block, (as indeed being "nuns"!). In general, men seem to preponderate in this field of Interfaith Dialogue. Some do not seem to realize that being women gives us an access to peoples' hearths and hearts in a way that men cannot easily find. And this not only in the villages with our simpler people, but also with the academicians and the more sophisticated who do not feel so threatened perhaps by women! We have often noticed that we can perceive things differently with our feminine intuition, how to enter certain situations, and could also get away with things!

In general, it might be true to say that the role of women in Interfaith Dialogue is probably not esteemed enough and is therefore often underplayed. Even the C.B.C.I. Guidelines for Inter-Religious Dialogue (see footnote 3.i) does not 
mention it-except to say that mothers should teach their children to respect others' faiths. However, "Word and Worship" once did invite us to share on this subject.9 We realized above all that the feminine art of listening and learning was fundamental to successful Dialogue.

\section{Living with - Listening to - Learning from}

Having seen the challenges of Dialogue, we might now look at what I would consider the fundamental prerequisites of the process. This formula of three L's is, one might say, the formula of Love and of apostleship, and at the same time, the necessary discipline and ascesis of Dialogue. Is not this how the disciples of Jesus began? St. Mark explicitly says: "He appointed twelve, that they might be with Him that He might send them out to preach..." (Mark 3.14). It is only by living with people that we can really get to "learn" them, know them, as it were, from the inside, without their masks, or clothes "put on specially for going out!" To live together in peace and harmony anywhere (as both married people and those living in communities well know) is a long, learning process. "With" is not enough; there must be also a "to" and a "from."

To teach we have to learn

"This is what brings us true communication (which is always communicatio in sacris) and frees us from the illusion that we can teach without having previously learned. To learn is to become a disciple and not a master; furthermore, it is to be converted to the world of the things learned." And this is just what happened to us. ${ }^{10}$

The more we tried to understand the "why" and "how" of what our Hindu friends believed and did, the more beauty and sense we began to see. And this "seeing" or darshan was in the face of the Christ hidden therein. The more we learnt and "saw" the Truth, the more the conflicts and contradictions (in their beliefs), which we had at first found or rather expected to find, disappeared.

"I cannot understand the other if I do not also believe that in a certain sense he or she also has the truth. Only truth is intelligible." Here, Panikkarji says, we can approach a genuine phenomenology of religion. ${ }^{11}$

Living and learning in Ashrams

This learning process began more profounding for us in Ashram. We had already visited over 30 Ashrams (Hindu and Christian) in different parts of India. We had also lived for three years in the Ecumenical Christ Prem Seva Ashram in Pune, begun in 1927 by Jack Winslow, the great English Anglican clergyman and Indian patriot, and reopened by us as an Ecumenical Ashram in 1971. Besides the three Anglican Sisters and six Catholic religious of the Sacred Heart, there was an old, cultured Brahmin lady in the community from the beginning-until she "left the body" (as our Hindu friends would say). We learnt much from her. She was an encyclopedia of Maharashtra Hindu ways of thought, bhakti, customs etc.

Three great, saintly men start us off

Above all, the first month there, we had the privilege of having with us Swami Abhishiktananda and a saint-scholar Pandit Dada Sahebh along with his CMI disciple, Prasannabhai. ${ }^{12}$ They both initiated us into the ashram lifestyle and 
especially taught us how to appreciate the Upanishads and the Bhagavad Gitā. I had no idea then what a great impact Swamiji was to have on me. Thanks too, to $D r$. Lederle S.J. ${ }^{13}$ we were introduced to many educated Hindu friends, places of pilgrimage, Bhajan mandalis (sacred music societies) etc. Our Hindu-Christian dialogue began thus in a natural way.

We also organized a three-day Inter-Faith 'Live-Together' Meeting in 1972 (our first experience of hosting a Sanatan-Eesai Satsanga) where we had the joyous privilege of having Sri Swami Chidanandaji of Rishikesh living with us. However, it was from 1973 onwards that we began our serious sadhana and learning process in Hindu Ashrams (predominantly in one) for the next five years.

\section{In "Hindu" Ashrams}

Having said "Hindu Ashrams" I am immediately reminded of Sri Swami Krishnanandaji saying on several occasions "We are not a 'Hindu' ashram!" meaning, presumably, that an ashram is meant to be open to any and all Godseekers. This was, perhaps, a seed falling into our hearts though we did not realize it then - that "In Christ there is not only no Jew nor Gentile" but also "No Hindu nor Christian." But to recognize it in reality and also what is meant by "Christ" took time.

Another Hindu friend of ours in Jaiharikhal drives this lesson home more deeply. This Sanskrit professor known as Shastriji (and who incidentally started us off, the very first week of our arrival, in our bi-weekly Ashram Hindu-Eesai Satsangs) says: Why think of people as Hindus, Muslim, Sikh, Jain, Christian? Why not as human beings? I would like to add also (and try to in our Ashram living) "Why Brahmins and Harijans"?

\section{All Human beings}

This attitude, I feel, should be Lesson 1 in our learning the art of Inter-Faith Dialogue. The more human we become and the more we stress our human kinship, the more we will find that nothing of another faith or culture is alien to us. "Nothing human is alien to me." This is especially so with Hinduism for Indians. Is it not part of our Indian heritage, and today so widely embraced even in the West precisely because of its humanness and openness. For it is not a "missionary" religion in the same sense as Buddhism, Christianity and Islam - though no doubt, today it has many more of its Vivekanandas abroad. And as Asians, we could extend this human "fellowship" to all our friends of other Eastern religions (which also includes Christianity, though we often seem to forget this). And, eventually, as we grow in this learning process, there will be in Christ, "neither East nor West" for us either. The prayer made by Jesus Christ will then indeed be fulfilled - "that they may be one, as Thou, Father, and I are one" (John 17.4).

\section{Learning in Rishikesh}

We were lucky to begin our Second Stage of Formation in Dialogue at the feet of Spiritual Masters in this "holy" place, famous as a "source" of Hindu spirituality, by the sacred river lovingly called Ganga Mata (Mother), nestling in the foothills of the great "Father" Himalayas; its natural beauty an asset for meditation. Everything 
here sings, speaks, shouts, smells of God and the quest of the Absolute. There is no other place in the world quiet like this - though I have seen many beautiful lands.

\section{Pilgrimages}

It is from here that thousands of pilgrims each year set off to the four higher tirtha's (places of pilgrimage): Badrinath, Kedarnath, Gangotri, Jamnotri. A pilgrimage of this kind is a natural part of life here. And living with the Ashramvasis implies entering into all their activities. My first pilgrimage was to Badrinath - in the company of five Hindu friends-mostly in silence or singing, "Badri Narayana, Narayana, Narayana." The one to Gangotri and thence $14 \mathrm{~km}$. on foot to Gomukh (the very source of the Ganga) was an experience for a lifetime. To reach the Source one has to touch death in some way, and I had the grace of this experience on this pilgrimage. An inner pilgrimage with our Hindu friends also means touching a kind of death - to our own ways of looking at things.

\section{Festina lente}

Once this death is accepted the dialogue moves more smoothly. But it is a slow process; a non-hurrying, oriental attitude about the pace of growth in communion. One must "hasten slowly" and have a scrupulous and quiet respect for what one does not manage to understand or agree with. After just a little experience, one learns that it is no use wanting to debate or argue it out. That could only block the attitude of dialogue (which brooks no competition) and stir up the feeling of "I must show I am more right!" Let those things be left intact until "a moment of greater understanding" dawns. This requires not only self-control but tolerance, which Panikkar calls "mystical patientia."

\section{As vidya decreases}

Only thus, little by little, as avidya (non-knowledge-sounds better than ignorance!) through dialogue decreases so, little by little, one loses one's old fears, prejudices, awkwardnesses. Once one's pride and security in the rightness of one's own position diminish, one begins to see the light where one thought that there was only darkness; beauty, where one imagined there was ugliness or superstition. Perhaps I could be permitted to give a few personal examples of what I mean?

a) The touching of feet, for instance, can become very meaningful once one realizes that it is not "my" feet being touched, or so and so's, but the Lord's - in that person. Then the question who is, or who is not worthy to have his/her feet touched does not arise. What more beautiful Indian way is there of humbling oneself? Some Hindu saints advised this sadhana of Dandvat Pranam (prostrating fully) as a means of ridding oneself of one's ahamkar (ego-self) and surrendering oneself to God completely. Even though, as a child, I was taught to touch the feet of my parents and elders, I had never really understood the significance of this and other beautiful gestures until I began living with Hindu friends. Seeing, for example, Sri Swami Chidanandaji doing it with reverence to "the least of his brethren"-leprosy patients or landlords, harijans or high dignitaries was a living example of simplicity. 
b) Being at the feet of an authentic guru (for not all who proclaim themselves as "Sri Sri Mahamandleshwar 1008" are authentic) was instructive too. Watching him all day, hearing his talks, responses, corrections, directions, (most spiritual direction is given in public, generally at darshans) one can learn so much of Hindu spirituality from within.

Unless one has been a disciple, can one become a guru? Christians are usually not only chary of the Gurushishya relationship, but are in too much of a hurry to become teachers, pastors, evangelizers, to save/liberate others. But not only they. Once I recall a Hindu asking Sri Swami Krishnanandaji "Is it true that today there are very few real gurus?" He answered "Yes-But I will tell you something more. There are even fewer disciples! Everyone wants to be a guru straightaway and fast!" That Eastern wisdom is slow and sure, with no short cuts of "get holy quick" ways of spirituality, I learnt by experience.

c) Praying together. Living together naturally involved daily chanting, bhajans, kirtans, Nama japa, praying for world peace at nightly Satsangs or at Akhand (non-stop) chants for days before big festivals, like Shivratri. Ceremonies and forms of worship at first looked at respectfully, but from a distance, gradually gave place to a better understanding of discreet participation, (without any sense of guilt), entering into the Spirit (who is One) of prayer, worship, love.

d) The Word. The daily readings, commentaries, study and chanting of the Scriptures, the Upanishads and the Bhagavad Gita particularly the chanting of a chapter of the Gita each day while lunch was being served began to open up tremendously new vistas. Through Dialogue with Hindus we learnt the value of chanting the Scripture. As far as I know, Christians are the only people (at least in India, where practically all the major religions are found) who do not recite the Scriptures in a chant tone. This is because we know them mostly in translation, I suppose, and the vast majority of us (except the Syrian Christians), Syro Malankara and Jacobite were introduced to them via the West. Personally, I think a great deal of even emotional content is taken out when Scriptures are spoken and not recited. As a child I was used to reciting Avesta Pehlvi-no doubt without comprehension! When as a youth I met Christ and fell in love with him I felt as though something vital was left out of my prayer life, even though I realized that I had gained far more in being able to speak to God in my own tongue, and in my own words, too.

This strikes me as another possible point of contact missed - when it comes to inviting Hindus to "pray" with us. True, we can chant Christian Japa's and share bhajans and kirtans, but that is different. There is a specific grace, I feel, in chanting/singing the Word of God - the way the Ramayana or the Gita are done. We need more Ishayana than we have and to spread it in the various Indian languages. Somehow it seems easier than to pass from the Word into Silence. Christians often want to talk and share their understanding of the Word after hearing it read. Hindus would normally flow from their chanting into silence. 


\section{Dialogue in silence}

We are so used to thinking of communication being done through words that we think of Dialogue too as being done only by speech - or sometimes by action. But one can, as we all know, communicate through body language and most profoundly through silence. Our mass communication media limit us to Western methods that most of us are familiar with today. Four years ago I was, for some unknown reason, invited for an International Catholic Press Conference, taking place for the first time in India. I noticed that no Indian had any specifically Indian contribution to make. We repeated in different ways what the Western countries had to say about communication media - except for Father Barbosa's communication of the Good News through Bharat Natyam. On the last day I was asked to speak for just a few minutes on the subject by the Indian organizers. (To some friends I had pointed out the pity of this phenomenon.) It is rare that one meets Christians who are familiar with this medium of communication. Yet, in ancient times in India, and even in our own day and age, sages like Sri Ramana Maharishi (d. 1950) communicated truth and love mostly in silence.

If, as the contemporary Eastern orthodox lay theologian Paul Ekdokimov says, silence will be the language of the next century, we have this decade to hurry up and learn it. The learning of a language is more the learning of its silence than of its sounds. Ivan Illich in his Celebration of Awareness in his essay on the 'Eloquence of Silence' tells us that it is not so much the other person's words as her/his silences which we have to learn in order to understand. The science of linguistics has brought into view new horizons in the understanding of human communication. An objective study of the ways in which meanings are transmitted has shown that much more is relayed from one to another through and in silence than in words. The one who shows us that she/he knows the rhythm of our silence is much closer to us than the one who thinks she/he knows how to speak. The greater the distance between the two worlds, the more this silence (or interest shown in silence) is a sign of love.

\section{Two prerequisites for Communication in silence}

To communicate this, however, there are two prerequisites, it seems to me. The first is that the partners must both have some idea of "doing the truth", and secondly that both be "spiritual" people if the dialogue has to be genuinely deep.

Dialogue can, and often is excellently and most eloquently practised in action. But it does not necessarily mean projects and programmes well advertised and written up. Did not Jesus say our left hand should not know what our right hand does, and that we should so let our light shine before men, that seeing (not hearing about) our good works, they may glorify the Father in heaven? This sort of teaching of Jesus (especially when they see it practised) Hindus are well able to understand. Is it not the same message as the selfless service for lokasangraha; the welfare of the world in the Bhagavad-Gitä?

Secondly, it has been my experience that deep understanding in spite of religious differences can be attained if both partners in the dialogue are "spiritual" people rather than "religious," i.e., people who try to live in and by the Spirit, rather than those who give prime importance to the, legal and external aspects: dogmas and 
doctrines, rites and rituals. It is possible then to feel much closer - even cor unum et anima una (one heart and one soul) as the Acts of the Apostles describe the early Christian communities - to those who are on the same spiritual wavelength as oneself, even though they may belong to another religion, than people who may share the same faith yet are poles apart in spirit, in the way they see their paths to God. Pilgrims on the Inner journey, no less than the outer one, if they are to feel fellowship, must walk on the same path. Otherwise they will be able to meet and hold real dialogue only when they arrive at their journey's end!

This requires not necessarily that they have the same theology, but that their spiritual lives cross intimately enough for them to share contemplation, be comfortable in silence, that they be mystics, or at least mystics-in-the-making. At this level dialogue brooks no differences for they know experientially that they are one in the Spirit who is Ekatvam.

\section{Notes}

1. M. M. Thomas: The Acknowledged Christ of the Indian Renaissance. (SCM Press Ltd., London, 1969).

2. $\quad$ R. Panikkar: "In Christ there is neither Hindu nor Christian: Perspectives on Hindu-Christian Dialogue." Chapter 20 of Religious Issues and Inter-Religious Dialogues, edited by C. Weihsun Fu and G. E. Spiegler (Greenwood Press, New York, 1989), p. 475.

Various aids are being offered us (the laity) in practical forms, in the shape of meetings, books, etc. To give but three references I have found useful: i) Guidelines for Inter-Religious Dialogue, Second Revised Edition. (CBCI Commission for Dialogue and Ecumenism, CBCI Centre, New Delhi 110 001). ii) My neighbour's Faith and Mine (World Council of Churches, Geneva, 1988). This book has excellent passages from various Scriptures, reflections and discussion questions for dialogal study groups. iii) Spirituality in Inter-Faith Dialogue. Tosh Arai and Wesley Ariarajah (W. C. C. Publications, Geneva, 1989). Opens up fresh vistas and concrete hopes of the Indian Church's growing maturity.

3. R. Panikkar: Authentic theology, though it never ceases to be theoretical reflection, must always be practical. Idem,. p. 479.

4. As Dr. Panikkar cogently points out, however, this appellation of "Hinduism" has endowed it with a certain unity. It in fact represents the beliefs of atheists, deists, monotheists, dualists, animists, and non-dualists - all of whom may call themselves Hindus. Idem., p. 477.

5. Once a holy Franciscan even wrote to me of the Lord Jesus' warning: S/he who denies me before men will be denied by my Father! But we never "denied" Christ. To be discrete, silent, not flaunting the cross was not, for us, to "deny Christ"! but to make Him present by our presence.

6. Felix Wilfred: "The Asian Realities Challenging the Church Today" at FABC Meeting, Tokyo, 1986. Quoted in SEFRI Papers (Service of Faith and Religion in India), Dec. 1986 (X. Irudayaraj S. J., 98 Santhome High Road, Madras 600 028).

7. Isa Up.6; Bhagavad Gïta 6.20 "He sees himself in the heart of all beings and he sees all beings in his heart." (Mascaro, Penguin Classics, 1965, 1960). 
8. Jeevan Dhara Ashram, in Jaiharikhal - a little village, unknown (like Nazareth in Galilee) situated in Pauri Garhwal, Himalayas.

9. Vandana and Ishpriya: "Word and Worship" 1988.

10. R. Panikkar, idem., p. 482.

I do not hesitate to quote literally from Dr. Panikkar's writings, not only because of his theological scholarship, experience and expertise of the wisdom of Hinduism, but also because his perspectives on Hindu-Christian Dialogue consistently confirm and corroborate our own experiences and ways of acting in our Dialogue with Hindus. I naturally find this thoroughly heartening!

11. Idem., pp. 482-83: "Here we approach a genuine phenomenology of religion if we succeed in transforming the Husserlian noema into what I have taken the liberty of calling the pistema. In other words, the belief of the believer is itself part and parcel of the religious phenomenon. If I do not arrive at the shared pistema, the belief of the believer, I am left with only a purely objective noema, and I will not have truly described the phenomenon..." And he proceeds to show in the same chapter that there is no Christian doctrine that one cannot more or less find in Hinduism. The Trinity, the Incarnation, the love of neighbour, the Resurrection-all of these things may be found in Indian wisdom. And that there is no general Hindu doctrine that cannot be interpolated in a Christian way. And, I would add, this is true of their Scriptures too-naturally.

12. Fr. Prasannabhai CMI was an interesting phenomenon for the early 70's! It was most unusual (and exciting) to see a priest be a humble disciple of a Hindu Guru and Pandit. As soon as the pair of them arrived at the Ashram (which they did often after this first encounter) he would see to Panditji's culinary needs - ekadasi fast, etc., then wash and hang out his clothes. He was supposed to be his Sanskrit student, but moving about with him from Ashram to Ashram, he learnt very much more about Hindu ways of thought, worship, spirituality than just Sanskrit. Yet, however busy the day may be, one saw them at their daily Sanskrit lesson - usually under a tree. It was a wonderfully fresh sight to behold - a priest act as a serving/servant disciple, instead of what was far more normal, having his clothes washed and other needs seen to by someone else - often a sister!

13. Dr. Mathew Lederle S. J. was himself a pioneer in Dialogue in Pune. Along with Dr. Deleury, he began living in a very Brahmin area. Because of his sanctity, simplicity and scholarship he was accepted and esteemed - in spite of being a Christian "missionary". Hopefully a biography will tell us of his interesting exploits in Dialogue: artistic, philosophical and for social justice too. Art India which promotes Indian Christian Art was his inspiration, as well as the works of many artists who were encouraged by him. 